\title{
Community knowledge and utilization of mangroves in Panabo Mangrove Park, Panabo City, Davao del Norte, Philippines
}

\author{
JEMER A. ALIMBON ${ }^{1, \vartheta}$, MARK RONALD S. MANSEGUIAO ${ }^{2, v v}$ \\ ${ }^{1}$ Department of Teacher Education, UM Tagum College. Mabini St., Tagum City 8100, Davao del Norte, Philippines. \\ Tel.: +63 907-943-6788, ‘email: alimbon.jemer@gmail.com \\ ${ }^{2}$ Institute of Teacher Education, Davao del Norte State College. New Visayas, Panabo City 8105, Davao del Norte, Philippines. \\ • email: markronald.manseguiao@dnsc.edu.ph
}

Manuscript received: 30 July 2021. Revision accepted: 15 September 2021.

\begin{abstract}
Alimbon JA, Manseguiao MRS. 2021. Community knowledge and utilization of mangroves in Panabo Mangrove Park, Panabo City, Davao del Norte, Philippines. Intl J Bonorowo Wetlands 11: 51-57. Awareness of community knowledge and utilization patterns of mangrove ecosystems and their services is integral to conservation and management. However, this aspect remains less explored, especially in the Philippines. Hence, this study assessed the community knowledge and utilization of mangroves in Panabo Mangrove Park, Panabo City, Davao del Norte Philippines, using a survey research design. Through a simple random sampling procedure, 154 residents living near the area were surveyed using a questionnaire. Data were analyzed using frequency and percentages. Results revealed that the majority were knowledgeable of the existence and the services of mangroves except for their medicinal uses. It was also found out that many respondents have more minor to no knowledge of the different species of mangroves. Further, most respondents reported that they used the mangrove ecosystem as a food source on varying frequencies but never utilized it for other purposes such as fuelwood, medicine, dyeing agent, construction materials, fishing poles, household furniture, and other items.
\end{abstract}

Keywords: Community knowledge, utilization, ecosystem services, mangroves, Philippines

\section{INTRODUCTION}

Mangroves are a community of plants comprised of many species (see Tomlinson 1986; Primavera 2009; Spalding et al. 2010; Duke 2011; Lebata-Ramos 2013), which are known to be ecologically tolerant as they can survive in extreme conditions such as hypersalinity and high solar radiation (Adame et al. 2021). Worldwide, this ecosystem, which links the marine and terrestrial ecosystems, is considered one of the most productive (Sreelekshmi et al., 2021). The mangrove ecosystems are recognized for their roles in maintaining marine biodiversity in tropical and subtropical regions and their functions in the global biogeochemical processes and climate change mitigation (Wang and Gu 2021).

Moreover, mangroves are known to affect human wellbeing (Hsieh et al. 2015; Akanni et al. 2018) through their immense provisioning, regulating, supporting, and cultural ecosystem services (Primavera et al. 2018; Kadaverugu et al. 2021). These benefits include providing food and livelihood to residents (Sawairnathan and Halimoon 2017; Barua and Rahman 2019; Gevaňa et al. 2019; Quevedo et al. 2019). For example, the locals sell the fish, fuelwood, and logs in the market in exchange for cash to sustain their needs (Nfotabong-Athuell et al., 2009; Shah and Datta, 2010). The mangrove ecosystem also serves as a source of raw materials for charcoal making and construction (Nfotabong-Athuell et al. 2009; Sinfuego and Buot 2014; Gonzales et al. 2017). Other benefits include medicinal uses such as Rhizophora spp. as a treatment for external hemorrhage and tooth decay (Nfotabong-Athuell et al. 2011) and Avicennia marina for sunburn (Arbiastutie et al. 2021).

However, knowledge deficits of the mangrove ecosystem and its services exist (Dencer-Brown et al., 2018). As noted, local populations have limited knowledge of mangrove species and their ecological and economic benefits (Satyanarayana et al., 2012). Darkwa and Smardon (2010) even found out that fishers lack the scientific knowledge necessary to derive the benefits offered by mangroves ultimately. Another concern is that destruction is inevitable because of community dependence on its known consumptive uses like charcoal making (Kusmana and Sukwika 2018; Ritabulan et al. 2019). Anthropogenic threats to mangrove include firewood overharvesting, house construction, timber production, agriculture, and aquaculture activities (Nfotabong-Athuell et al. 2011; Warren-Rhodes et al. 2011; Jones et al. 2015; Gonzales et al. 2017; Marican et al. 2018) and, more recently, ecotourism (Ramli et al. 2018; Mahmood et al. 2021) and urban expansion (Moschetto et al. 2021).

These knowledge inadequacies and unsustainable human interventions primarily pose enormous challenges to mangrove conservation and restoration (Biswas et al., 2009). Though efforts were made, apparent gaps on how stakeholders (e.g., community members) can transform initiatives into actions for sustainable development are still evident (Garcia et al. 2014). Effective management and conservation of mangroves require knowledge of their ecosystem services (Friess et al. 2016). In the Philippines, 
very few studies (i.e., Quevedo et al. 2019; Tejada and Cauilan 2019; Ballad and Mangabat 2021) explored the local knowledge and perspectives on mangroves and their utilization. In Davao Gulf, which is found in the southeastern part of the Philippines, studies were primarily focused on the assessment of mangrove species diversity (Jumawan et al. 2015; Pototan et al. 2017, 2021; Cardillo and Novero 2018) and recently included aboveground biomass and carbon stock (Alimbon and Manseguiao 2021). Hence, this study aimed to assess mangroves' community knowledge and utilization in Panabo Mangrove Park, Panabo City, Davao del Norte, Philippines. The results of this study are expected to provide baseline information on the sociodemographic profile, level of knowledge, and extent of utilization of the residents. Having this relevant data would help the authorities make informed decisions on the mangrove management and conservation efforts, especially those that involve the local populations.

\section{MATERIALS AND METHODS}

\section{Study area}

This study was conducted in Barangay J.P. Laurel, Panabo City, Davao del Norte, Philippines (Figure 1) last April 2019. It is located in the southeastern portion of the city facing Davao Gulf. This coastal village hosts the Panabo Mangrove Park (7¹6’20.579' N, 125 40'50.984" E). This mangrove community houses several mangrove species, including Aegeciras corniculatum, Avicennia marina, Rhizophora apiculata, Rhizophora mucronata, and Sonneratia alba (Alimbon and Manseguiao 2021). Based on the 2015 Census of Population, Barangay J.P. Laurel had a population of 6,561 individuals (Philippine Statistics Authority, 2015).

\section{Research design}

This is a quantitative type of research employing a survey research design (Creswell 2012) to assess the community knowledge and utilization of mangroves in the area.

\section{Research respondents}

The respondents of this study were the residents inhabiting near or adjacent to the mangrove community. This study only included those living within the 500-m radius from the boundary of the mangrove park. A total of 154 respondents were selected using random sampling. This sample size was determined using Slovin's formula: $n$ $=\mathrm{N} /\left(1+\mathrm{Ne}^{2}\right)$, where $\mathrm{n}$ is the sample size, $\mathrm{N}$ is the population size, and e is the margin of error set at 0.05 .

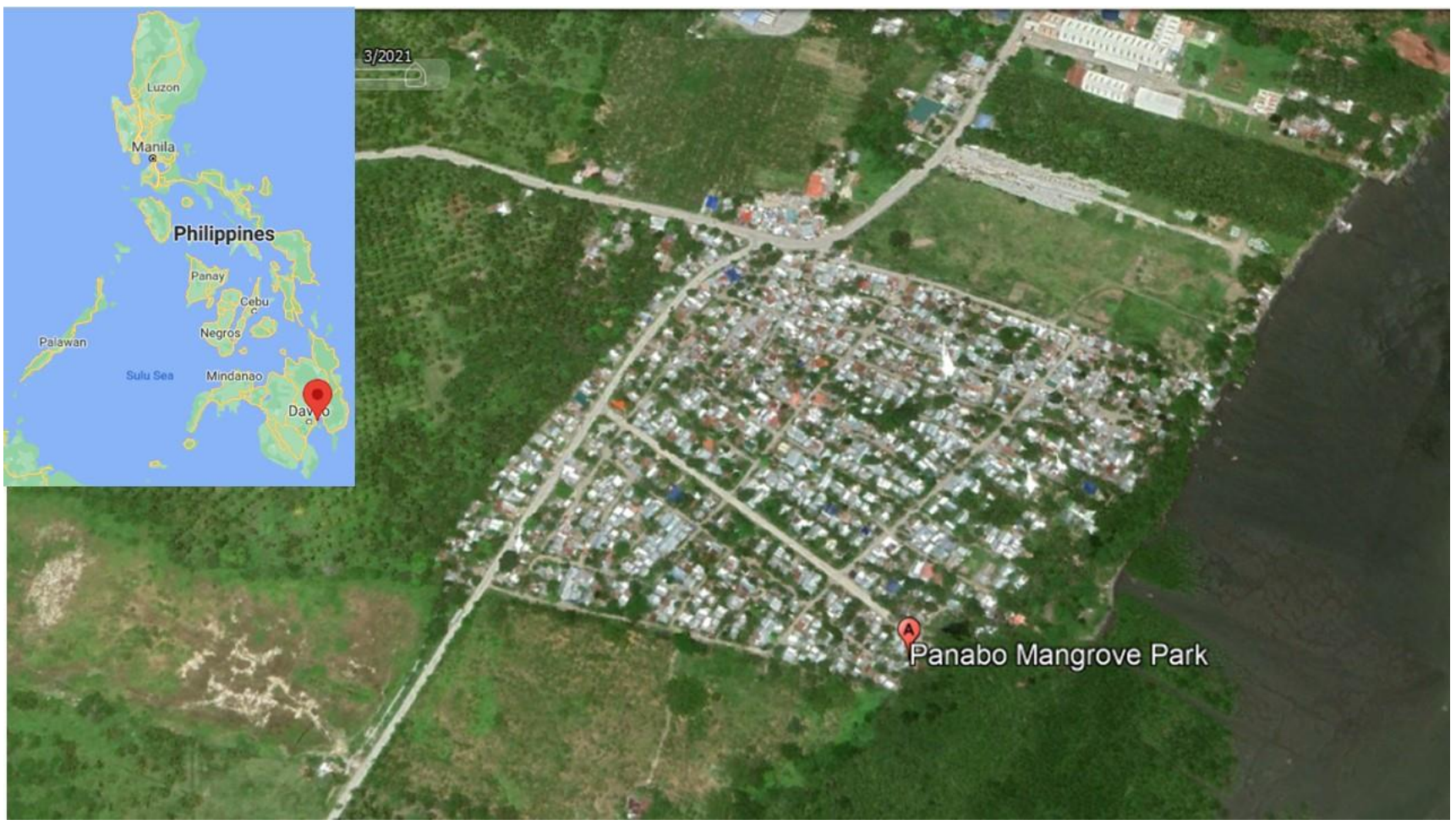

Figure 1. Location of Panabo Mangrove Park, Panabo City, Davao del Norte, Philippines (Google Earth, 2021) 


\section{Research instrument}

This study utilized a structured questionnaire designed to determine (1) the demographic profile of respondents, (2) the level of community knowledge, and (3) the extent of community utilization of mangroves. The questionnaire was translated into a local dialect of Panabo City, Philippines, to be easily understood. Indicators for community knowledge and utilization of mangroves were assessed using a 4-point Likert scale. To ensure validity, the instrument underwent content validation by experts. To ensure reliability, it was pilot tested to community members who are not included in the study yet, inhabit near a mangrove area. Inconsistencies noted during reliability checks were corrected before the actual data gathering.

\section{Data analysis}

Data on the demographic profile of residents, levels of community knowledge, and the extent of utilization were tabulated and analyzed using frequency and percentages.

\section{RESULTS AND DISCUSSION}

\section{Profile of the respondents}

Table 1 presents the demographic profile of the respondents. The majority of the respondents are aged 21 30 years old at $24.0 \%$, males at $51.30 \%$, and married at $66.2 \%$. Most of them $(55.8 \%)$ reached or finished secondary education, while few $(2.60 \%)$ did not have formal education. In terms of occupation, only $5.8 \%$ of the respondents are into fishing which means that most are not into fishery-related or coastal-resource-utilization-related work. These include housewives $(27.3 \%)$, skilled workers (26.6\%), students $(22.1 \%)$, businessmen $(11.7 \%)$, private employees $(3.3 \%)$, government employees $(2.6 \%)$, and farmer $(0.7 \%)$. Most of the respondents, at $31.2 \%$, claimed to have resided in the area for five years or less, which means that they recently moved into the area. This influx of residents in the area should be monitored, for Chong (2006) mentioned that increasing coastal population could potentially cause mangrove degradation. In terms of income, $83.8 \%$ of the respondents earned Php $10,000.00$ or less $(\leq$ USD 200), which is lower than Php 10,756.00 $(\approx$ USD 215), the average monthly poverty threshold for a family of five (PSA, 2020). This means that the monthly income of many families in the area is not sufficient to meet their minimum basic food and non-food needs.

\section{Level of community knowledge}

This study assessed the community's knowledge of mangroves' existence and ecosystem services in the area (Table 2). The result showed that most of the respondents $(81.1 \%)$ were very knowledgeable of the existence of mangroves in the area. Surprisingly, a few reported having less to nonknowledge of its presence, at $6.5 \%$ and $3.9 \%$, respectively. This could be because they recently moved into the area since most respondents claimed to have lived there for only five years or less.
Table 1. Demographic profile of the respondents

\begin{tabular}{|c|c|c|c|}
\hline \multicolumn{2}{|c|}{ Demographic variables } & \multirow{2}{*}{$\begin{array}{l}\mathbf{n} \\
79\end{array}$} & \multirow{2}{*}{$\begin{array}{l}\% \\
51.3\end{array}$} \\
\hline Sex & Male & & \\
\hline & Female & 75 & 48.7 \\
\hline \multirow{5}{*}{ Marital Status } & Single & 44 & 28.6 \\
\hline & Married & 102 & 66.2 \\
\hline & Widowed & 5 & 3.3 \\
\hline & Others (e.g., live-in) & 2 & 1.3 \\
\hline & $\begin{array}{l}\text { Did not provide } \\
\text { information }\end{array}$ & 1 & 0.7 \\
\hline \multirow[t]{7}{*}{ Age } & 20 and below & 36 & 23.4 \\
\hline & 21 to 30 & 37 & 24.0 \\
\hline & 31 to 40 & 30 & 19.5 \\
\hline & 41 to 50 & 23 & 14.9 \\
\hline & 51 to 60 & 16 & 10.4 \\
\hline & 61 and above & 9 & 5.8 \\
\hline & $\begin{array}{l}\text { Did not provide } \\
\text { information }\end{array}$ & 3 & 2.0 \\
\hline \multirow[t]{6}{*}{ Education } & No formal education & 4 & 2.6 \\
\hline & Elementary & 38 & 24.7 \\
\hline & Secondary & 86 & 55.8 \\
\hline & College & 18 & 11.7 \\
\hline & Graduate/Post-graduate & 2 & 1.3 \\
\hline & $\begin{array}{l}\text { Did not provide } \\
\text { information }\end{array}$ & 6 & 4.0 \\
\hline \multirow{6}{*}{$\begin{array}{l}\text { Number of } \\
\text { years in the } \\
\text { area }\end{array}$} & 5 and below & 48 & 31.2 \\
\hline & 6 to 10 & 29 & 18.8 \\
\hline & 11 to 15 & 27 & 17.5 \\
\hline & 16 to 20 & 12 & 7.8 \\
\hline & 21 or more & 35 & 22.7 \\
\hline & $\begin{array}{l}\text { Did not provide } \\
\text { information }\end{array}$ & 3 & 2.0 \\
\hline \multirow[t]{8}{*}{ Occupation } & Fisherman & 9 & 5.8 \\
\hline & Farmer & 1 & 0.7 \\
\hline & Housewife & 42 & 27.3 \\
\hline & Student & 34 & 22.1 \\
\hline & Businessman & 18 & 11.7 \\
\hline & Government employee & 4 & 2.6 \\
\hline & Private employee & 5 & 3.3 \\
\hline & $\begin{array}{l}\text { Others (i.e., skilled } \\
\text { workers) }\end{array}$ & 41 & 26.6 \\
\hline \multirow{3}{*}{$\begin{array}{l}\text { Monthly } \\
\text { income }\end{array}$} & $\mathrm{PhP} 10,000.00$ and below & 129 & 83.8 \\
\hline & $\begin{array}{l}\mathrm{PhP} 10,001.00 \text { - } \mathrm{PhP} \\
20,000.00\end{array}$ & 23 & 14.9 \\
\hline & $\begin{array}{l}\mathrm{PhP} 20,001.00-\mathrm{PhP} \\
30,000.00\end{array}$ & 2 & 1.3 \\
\hline
\end{tabular}

Note: US\$ $1.00 \approx \operatorname{PhP} 50.00$

Despite the very high knowledge about mangrove existence demonstrated by most surveyed residents, results showed that many have more minor to non-knowledge of the different species of mangroves, both at $31.2 \%$. Notably, during the survey, respondents could only provide generic local names of Avicennia, Sonneratia, and Rhizophora species. Only very few respondents could provide local terms specific for $R$. apiculata and $R$. mucronata. This observation is quite similar to the findings of Nfotabong- 
Athuell et al. (2011), which revealed that residents near mangrove forests are only familiar with one to four species. Longépée et al. (2021) also found that their respondents have lower local ecological knowledge regarding the number of mangrove species and their names.

Community knowledge on provisioning services of mangroves was also asked. Many respondents reported that they were very knowledgeable on the following services: food source $(59.7 \%)$, fuel resource $(51.9 \%)$, and construction and fishing materials (44.8\%). Awareness that mangroves provide one or all of these benefits was documented in several studies (e.g., Dencer-Brown et al. 2019; Quevedo et al. 2019; Setiyaningrum 2019; Wahyuni et al. 2021). Most locals recognize these benefits due to their perceived importance and direct value to human livelihood (Nyangoko et al., 2021). Interestingly, many surveyed residents were not knowledgeable of mangroves being a source of firewood and charcoal at $24.7 \%$ and construction and fishing materials at $27.9 \%$. Further, the community seems to have limited knowledge of the medicinal use of mangroves since $76.0 \%$ of the respondents claimed not to know this benefit. Similar accounts were reported wherein respondents demonstrate a doubtful understanding of the medicinal benefits of mangroves (Sulaiman et al. 2019; Wahyuni et al. 2021). Nyangoko et al. (2021) even found that local inhabitants perceive this benefit as unimportant compared to other provisioning services.

Further, knowledge on supporting and regulating services of mangroves was assessed. Most surveyed respondents were knowledgeable about mangroves being a habitat and a nursery or spawning ground for other organisms, at $70.8 \%$ and $71.4 \%$, respectively. In addition, $74.0 \%$ of the locals were very knowledgeable about the mangrove community as protection from coastal erosion and intense winds and waves during storms. In comparison, $38.3 \%$ were very knowledgeable on the role of mangroves in oxygen release and carbon sequestration. Residents' significant knowledge of the above benefits could be attributed to their educational attainment. Education is regarded as an essential factor that elevates ability and determines the understanding of residents about the mangrove ecosystem (Abd Rahman and Asmawi 2016; Sawairnathan and Halimoon 2017). As reflected in Table 1, $68.83 \%$ of the respondents reached secondary (high school) education. Secondary education allows residents to have minimum knowledge of the mangroves (Abd Rahman and Asmawi 2016). This record of local populations' sufficient knowledge affirmed the findings of several studies (Nfotabong-Athuell et al. 2011; Warren-Rhodes et al. 2011; Ferichani and Prasetya 2012; Da Silva 2015; Sawairnathan and Halimoon 2017; Tejada and Cauilan 2019), which mentioned that residents are aware of the goods and ecological services they benefit from the mangrove ecosystem.

\section{The extent of community utilization}

The extent of community utilization of mangroves was also assessed (Table 4). Many respondents (71.4\%) reported that mangroves serve as their food source on varying frequencies from rare occasions to all the time. The food items usually collected from the area were fish and shellfish. However, $28.6 \%$ of the surveyed locals never accessed the site to obtain food.

Though several studies (e.g., Dahdouh-Guebas et al. 2000; Nfotabong-Athuell et al. 2011; Da Silva 2015; Gonzales et al. 2017; Numbere 2019) already documented that local inhabitants used mangroves as firewood, charcoal, fodder, construction materials, fishing apparatus such as poles, medicine, dyeing agent, household furniture, and other items, very few respondents claimed to have benefited these uses of mangroves in the study site. Even as a source of income, only $16.2 \%$ reported to benefit from it. These income-generating mangrove-related activities included selling caught fish and shellfish and participating in activities initiated by the local government unit.

Table 2. Level of community knowledge of mangroves in Panabo Mangrove Park, Panabo City, Davao del Norte, Philippines

\begin{tabular}{|c|c|c|c|c|c|c|c|c|}
\hline \multirow[t]{2}{*}{ Community knowledge } & \multicolumn{2}{|c|}{$\begin{array}{c}\text { Very } \\
\text { knowledgeable }\end{array}$} & \multicolumn{2}{|c|}{$\begin{array}{c}\text { Moderately } \\
\text { knowledgeable }\end{array}$} & \multicolumn{2}{|c|}{$\begin{array}{c}\text { Less } \\
\text { knowledgeable }\end{array}$} & \multicolumn{2}{|c|}{$\begin{array}{l}\text { No knowledge } \\
\text { at all }\end{array}$} \\
\hline & $\mathbf{n}$ & $\%$ & $\mathbf{n}$ & $\%$ & n & $\%$ & n & $\%$ \\
\hline Mangroves exist near my area & 125 & 81.1 & 13 & 8.4 & 10 & 6.5 & 6 & 3.9 \\
\hline Mangroves have different species & 32 & 20.8 & 26 & 16.9 & 48 & 31.2 & 48 & 31.2 \\
\hline Mangroves serve as habitat for other organisms & 109 & 70.8 & 12 & 7.8 & 15 & 9.7 & 18 & 11.7 \\
\hline $\begin{array}{l}\text { Mangroves serve as a nursery ground for fish, mollusks, } \\
\text { crabs, and shrimp }\end{array}$ & 110 & 71.4 & 17 & 11.0 & 14 & 9.1 & 13 & 8.4 \\
\hline $\begin{array}{l}\text { Mangroves offer protection from coastal erosion and } \\
\text { intense wind and waves during storms }\end{array}$ & 114 & 74.0 & 12 & 7.8 & 13 & 8.4 & 15 & 9.7 \\
\hline Mangroves serve as a food source & 92 & 59.7 & 18 & 11.7 & 23 & 14.9 & 21 & 13.6 \\
\hline $\begin{array}{l}\text { Mangroves provide fuel resources (e.g., firewood, } \\
\text { charcoal) }\end{array}$ & 80 & 51.9 & 18 & 11.7 & 18 & 11.7 & 38 & 24.7 \\
\hline $\begin{array}{l}\text { Mangroves provide construction and fishing materials } \\
\text { (e.g., timber, fishing stakes, and fishing boats) }\end{array}$ & 69 & 44.8 & 25 & 16.2 & 17 & 11.0 & 43 & 27.9 \\
\hline Mangroves have medicinal use & 16 & 10.4 & 8 & 5.2 & 13 & 8.4 & 117 & 76.0 \\
\hline Mangroves release oxygen and absorb carbon dioxide & 59 & 38.3 & 26 & 16.9 & 26 & 16.9 & 43 & 27.9 \\
\hline
\end{tabular}


Table 3. The extent of community utilization of mangroves in Panabo Mangrove Park, Panabo City, Davao del Norte, Philippines

\begin{tabular}{|c|c|c|c|c|c|c|c|c|}
\hline \multirow{2}{*}{ Community utilization } & \multicolumn{2}{|c|}{ Always } & \multicolumn{2}{|c|}{ Sometimes } & \multicolumn{2}{|c|}{ Rarely } & \multicolumn{2}{|c|}{ Never } \\
\hline & n & $\%$ & $\mathbf{n}$ & $\%$ & $\mathbf{n}$ & $\%$ & $\mathbf{n}$ & $\%$ \\
\hline I use mangroves as a food source & 26 & 16.9 & 29 & 18.8 & 55 & 35.7 & 44 & 28.6 \\
\hline I use mangroves as construction materials for houses & 4 & 2.6 & 6 & 3.9 & 7 & 4.5 & 137 & 89.0 \\
\hline $\begin{array}{l}\text { I use mangroves as fishing materials (e.g., poles for fish traps, } \\
\text { rafts, boats) }\end{array}$ & 6 & 3.9 & 5 & 3.2 & 10 & 6.5 & 133 & 86.4 \\
\hline I use mangroves as medicine & 3 & 1.9 & 4 & 2.6 & 12 & 7.8 & 135 & 87.7 \\
\hline I use mangroves as firewood & 7 & 4.5 & 6 & 3.9 & 7 & 4.5 & 134 & 87.0 \\
\hline I use mangroves as charcoal & 5 & 3.2 & 2 & 1.3 & 5 & 3.2 & 142 & 92.2 \\
\hline $\begin{array}{l}\text { I use mangroves as house furniture (e.g., chairs, tables) and } \\
\text { household items (e.g., baskets, mortar, tool handles) }\end{array}$ & 7 & 4.5 & 6 & 3.9 & 9 & 5.8 & 132 & 85.7 \\
\hline $\begin{array}{l}\text { I use mangroves in agriculture (e.g., fence, fencing posts, fodder } \\
\text { [feeds]) }\end{array}$ & 8 & 5.2 & 4 & 2.6 & 10 & 6.5 & 132 & 85.7 \\
\hline I use mangroves as a dyeing agent & 4 & 2.6 & 1 & 0.6 & 5 & 3.2 & 144 & 93.5 \\
\hline I use mangroves as a source of income & 4 & 2.6 & 5 & 3.2 & 16 & 10.4 & 129 & 83.8 \\
\hline
\end{tabular}

This non-extensive utilization of mangroves can be attributed to the fact that most residents' occupations are not fisheries and other mangrove-related activities. Only nine $(5.84 \%)$ respondents claimed to be fishermen. Further, this could be due to the considerable knowledge of residents about laws and policies regarding conservation, protection, utilization, and development of mangroves (Sulistyowati and Astuti 2018). In the Philippines, cutting off all mangrove species is banned (Revised Forestry Code of the Philippines). Also, conversion of mangroves to fishpond or any purpose is declared unlawful under Republic Act No. 10654. As observed in the study site, a poster was hung reminding the public not to cut trees or build a structure within the mangrove forest.

Moreover, the result of this study was on the contrary of the findings of studies in a few countries in Africa where a large percentage of households living near mangrove forests still depend on these resources for subsistence and other economic needs (Nfotabong-Athuell et al. 2009; Da Silva 2015; Warui et al. 2020). In addition, Gonzales et al. (2017) found out that in Rio Tuba, Palawan, Philippines, the community still harvests mangrove trees for house construction and charcoal production. However, it was noted by Satyanarayana et al. (2012) that the trend of utilizing mangrove resources has now decreased.

In conclusion, the community is knowledgeable of the existence of mangroves in the area, but a significant number of the surveyed respondents did not know that mangroves have different species. Also, the majority are knowledgeable of the mangrove ecosystem services except for medicinal uses. In terms of utilization, it can be considered as not extensive except being a food source since many respondents reported that they obtain food (e.g., fish, shellfish) from the area at varying frequencies. This non-utilization of mangroves, incredibly destructive uses (e.g., fuelwood, charcoal) by most residents, could be due to their line of occupation and their awareness of existing laws that prohibit such acts.

\section{ACKNOWLEDGEMENTS}

We are grateful to the Graduate School-Davao del Norte State College and the local government of Panabo City, most especially the Barangay J.P. Laurel, for their support in the conduct of this study. Special thanks to the community members who voluntarily participated during the survey and to all who made this study possible. The authors declare no conflicts of interest regarding the publication of this study.

\section{REFERENCES}

Abd Rahman M, Asmawi MZ. 2016. Local residents' awareness towards the issue of mangrove degradation in Kuala Selangor, Malaysia. $\begin{array}{llll}\text { Proced-Soc Behav Sci 222: 659-667. DOI: } & \end{array}$ 10.1016/j.sbspro.2016.05.222.

Adame MF, Reef R, Santini NS, Najera E, Turschwell MP, Hayes MA, Masque P. Lovelock CE. 2021. Mangroves in arid regions: Ecology, threats, and opportunities. Estuar Coast Shelf Sci 248. DOI: 10.1016/j.ecss.2020.106796.

Akanni A, Onwuteaka J, Uwagbae M, Mulwa R, Elegbede IO. 2018. The values of mangrove ecosystem services in the Niger Delta Region of Nigeria. In: Ndimele PE (ed) The Political Ecology of Oil and Gas Activities in the Nigerian Aquatic Ecosystem. Academic Press, United Kingdom. DOI: 10.1016/B978-0-12-809399-3.00025-2.

Alimbon JA, Manseguiao MRS. 2021. Species composition, stand characteristics, aboveground biomass, and carbon stock of mangroves in Panabo Mangrove Park, Philippines. Biodiversitas 22 (6): 31303137. DOI: 10.13057/biodiv/d220615.

Arbiastutie Y, Diba F, Masriani. 2021. Ethnobotanical and ecological studies of medicinal plants in a mangrove forest in Mempawah district, West Kalimantan, Indonesia. Biodiversitas 22 (6): 3164 3170. DOI: 10.13057/biodiv/d220619.

Ballad EL, Mangabat CB. 2021. Perceptions of coastal villagers on the non-use values of mangroves in Cagayan Province, Philippines. Marit Technol Res 3 (4): 322-334. DOI: 10.33175/mtr.2021.248619.

Barua P, Rahman SH. 2019. Sustainable livelihood of vulnerable communities in southern coast of Bangladesh through the utilization of mangroves. Asian J Wat Environ Pollut 6 (1): 59-67. DOI: 10.3233/AJW190007.

Biswas SR, Mallik AU, Choudhury JK, Nishat A. 2009. A unified framework for the restoration of Southeast Asian mangroves-bridging ecology, society, and economics. Wetlands Ecol Manag 17 (4): 365383. DOI: $10.1007 / \mathrm{s} 11273-008-9113-7$. 
Cardillo J, Novero AU. 2018. Assessment of mangrove diversity in Santa Cruz, Davao del Sur, Philippines. J Biodivers Environ Sci 14 (2): $53-$ 62 .

Chong VC. 2006. Sustainable utilization and management of mangrove ecosystems of Malaysia. Aquat Ecosyst Health Manag 9 (2): 249-260. DOI: $10.1080 / 14634980600717084$

Creswell JW. 2012. Educational Research: Planning, Conducting, and Evaluating Quantitative and Qualitative Research (4th ed.). Pearson, Boston.

Da Silva P. 2015. Exploring a community's knowledge and use of a coastal mangrove resource: The case of Wellington Park, Guyana. Intl J Sci Environ Technol 4: 759-769.

Dahdouh-Guebas F, Mathenge C, Kairo JG, Koedam N. 2000. Utilization of mangrove wood products around Mida Creek "Kenya" amongst subsistence and commercial users. Econ Bot 54 (4): 513-527. DOI 10.1007/BF02866549

Darkwa S, Smardon R. 2010. Ecosystem restoration: Evaluating loca knowledge and management systems of fishermen in Fosu Lagoon, Ghana. Environ Pract 12 (3): 202-213. DOI 10.1017/S1466046610000256

Dencer-Brown AM, Alfaro A, Milne S, Perott J. 2018. A review on biodiversity, ecosystem services and perceptions of New Zealand's mangroves: can we make informed decisions about their removal? Resour 7 (1): 23. DOI: 10.3390/resources7010023

Dencer-Brown AM, Alfaro AC, Milne S. 2019. Muddied waters: Perceptions and attitudes towards mangroves and their removal in New Zealand. Sustainability 11 (9): 2631. DOI: 10.3390/su11092631

Duke NC. 2011. Mangroves. Encyclopedia of Earth Sciences Series. DOI: 10.1007/978-90-481-2639-2_108

Ferichani M, Prasetya DA. 2012. Learning from the grassroots: The indigenous knowledge on mangrove forest and the social, economic barriers in fostering local green economy of Ujung Alang village dwellers in Segara Anakan lagoon territory of Indonesia. Proceedings of the International Forestry and Environmental Symposium 2012 of the Department of Environmental Science. University of Sri Jayewardenepura, Sri Lanka.

Friess DA, Richards DR, Phang VX. 2016. Mangrove forests store high densities of carbon across the tropical urban landscape of Singapore. Urban Ecosyst 19 (2): 795-810. DOI: 10.1007/s11252-015-0511-3

Garcia KB, Malabrigo PL, Gevaña DT. 2014. Philippines' mangrove ecosystem: status, threats, and conservation. In: Faridah-Hanum I, Latiff A, Hakeem KR, Ozturk M (eds) Mangrove Ecosystems of Asia. Springer, New York. DOI: 10.1007/978-1-4614-8582-7 5

Gevaña DT, Pulhin JM, Tapia MA. 2019. Fostering climate change mitigation through a community-based approach: Carbon stock potential of community-managed mangroves in the Philippines. In Krishnamurthy RR, Jonathan MP, Srinivasalu S, Glaeser B (eds) Coastal Management: Global Challenges and Innovations. Academic Press, New York. DOI: 10.1016/B978-0-12-810473-6.00014-5

Gonzales B, Sariego R, Montano B. 2017. Social benefits and impacts of mangrove resource utilization in Rio Tuba, Bataraza, Palawan, Philippines. AES Bioflux 9 (2): 135-147.

Hsieh H-L, Lin H-J, Shih S-S, Chen C-P. 2015. Ecosystem functions connecting contributions from ecosystem services to human wellbeing in a mangrove system in Northern Taiwan. Int J Environ Res Public Health 12 (6): 6542-6560. DOI: 10.3390/ijerph120606542

Jones TG, Ratsimba HR, Ravaoarinorotsihoarana L, Glass L, Benson L, Teoh M, Carro A, Cripps G, Giri C, Gandhi S, Andriamahenina Z, Rakotomanana R, Roy PF. 2015. The dynamics, ecological variability, and estimated carbon stocks of mangroves in Mahajamba Bay, Madagascar. J Mar Sci Eng 3 (3): 793-820. DOI: 10.3390/jmse3030793

Jumawan J, Flores FL, Aragon RT, Villamor JMC, Sagot JC, Taguse, HC, Genecera J, Banas GG, Depamaylo AMV. 2015. Diversity assessmen and spatial structure of mangrove community in a rehabilitated landscape in Hagonoy, Davao del Sur, Philippines. AES Bioflux 7 (3): 475-482

Kadaverugu R, Dhyani S, Dasgupta R, Kumar P, Hashimoto S, Pujari P. 2021. Multiple values of Bhitarkanika mangroves for human wellbeing: synthesis of contemporary scientific knowledge for mainstreaming ecosystem services in policy planning. J Coast Conserv 25 (2): 1-15. DOI: 10.1007/s11852-021-00819-2

Kusmana C, Sukwika T. 2018. Coastal community preference on the utilization of mangrove ecosystem and channelbar in Indramayu, Indonesia. AACL Bioflux 11 (3): 905-918.
Lebata-Ramos M. 2013. Field guide to mangrove identification and community structure analysis. SEAFDEC Aquaculture Department, Iloilo, Philippines.

Longépée E, Abdallah AA, Jeanson M, Golléty C. 2021. Local ecological knowledge on mangroves in Mayotte Island (Indian Ocean) and influencing factors. Forests 12 (1): 1-23. DOI: 10.3390/f12010053

Mahmood H, Ahmed M, Islam T, Uddin MZ, Ahmed ZU, Saha C. 2021. Paradigm shift in the management of the Sundarbans mangrove forest of Bangladesh: Issues and challenges. Tree For People 5. DOI: 10.1016/j.tfp.2021.100094

Marican NW, Nawi NM, Kamarulzaman NH, Samdin Z. 2018. Public perception towards sustainable mangrove forest programs in Malaysia. J Sustain Sci Manag 13 (1): 189-199.

Moschetto FA, Ribeiro RB, De Freitas DM. 2021. Urban expansion, regeneration, and socioenvironmental vulnerability in a mangrove ecosystem at the southeast coastal of São Paulo, Brazil. Ocean Coast Manag 200. DOI: 10.1016/j.ocecoaman.2020.105418

Nfotabong-Atheull A, Din N, Essomè Koum LG, Satyanarayana B, Koedam N, Dahdouh-Guebas F. 2011. Assessing forest products usage and local residents' perception of environmental changes in peri-urban and rural mangroves of Cameroon, Central Africa. J Ethnobiol Ethnomed 7 (1): 1-13. DOI: 10.1186/1746-4269-7-41

Nfotabong-Atheull AN, Din N, Longonje SN, Koedam N, DahdouhGuebas F. 2009. Commercial activities and subsistence utilization of mangrove forests around the Wouri estuary and the Douala-Edea reserve (Cameroon). J Ethnobiol Ethnomed 5 (1): 1-14. DOI: 10.1186/1746-4269-5-35

Numbere AO. 2019. Perception of mangrove forest protection and utilization amongst residents in some coastal communities in the Niger Delta, Nigeria. Curr Trends For Res 3 (1039): 2638-3013. DOI: 10.29011/2638-0013.101039

Nyangoko BP, Berg H, Mangora MM, Gullström M, Shalli MS. 2021. Community perceptions of mangrove ecosystem services and their determinants in the Rufiji Delta, Tanzania. Sustainability 13 (1): 1-23. DOI: $10.3390 / \mathrm{su} 13010063$

Philippine Statistics Authority. 2015. Population of Panabo City (Based on the results of 2015 census of population). http://rsso11.psa.gov.ph/

Philippine Statistics Authority. 2020. Updated full year 2018 official poverty statistics of the Philippines. https://psa.gov.ph/

Pototan BL, Capin NC, Delima AGD, Novero AU. 2021. Assessment of mangrove species diversity in Banaybanay, Davao Oriental, Philippines. Biodiversitas 22 (1): 144-153. DOI: 10.13057/biodiv/d220120

Pototan BL, Capin NC, Tinoy MRM, Novero AU. 2017. Diversity of mangrove species in three municipalities of Davao del Norte, Philippines. AACL Bioflux 10 (6): 1569-1579.

Presidential Decree No. 705. 1975. Revised Forestry Code of the Philippines. https://www.officialgazette.gov.ph

Primavera JH, Friess DA, Van Lavieren H, Lee SY. 2018. The mangrove ecosystem. In World Seas: An Environmental Evaluation Volume III: Ecological Issues and Environmental Impacts. Academic Press, United Kingdom. DOI: 10.1016/B978-0-12-805052-1.00001-2

Primavera JH. 2009. Field Guide to The Philippine Mangroves. Philippine Tropical Forest Conservation Foundation, Inc. and Zoological Society of London, UK

Quevedo JMD, Uchiyama Y, Kohsaka R. 2019. Perceptions of local communities on mangrove forests, their services, and management: implications for Eco-DRR and blue carbon management for Eastern Samar, Philippines. J For Res 25 (1): 1-11. DOI: 10.1080/13416979.2019.1696441

Ramli F, Samdin Z, Abd Ghani AN, Kasim MRM. 2018. Factors affecting users' perception towards conservation of biodiversity in Matang Mangrove Forest Reserve (MMFR), Perak, Malaysia. Intl J Bus Soc 19: $26-36$

Republic Act No. 10654. 2015. An act to prevent, deter and eliminate illegal, unreported, and unregulated fishing, amending Republic Act No.8550, otherwise known as "The Philippine Fisheries Code of 1998," and for other purposes. https://www.officialgazette.gov.ph

Ritabulan, Basuni S, Santoso N, Bismark M, Yusuf DN, Karlina E. 2019. Modeling of policy for mangrove utilization as a charcoal raw material in the local community in Batu Ampar, West Kalimantan. IOP Conf Ser: Earth Environ Sci 382 (1). DOI: 10.1088/1755$1315 / 382 / 1 / 012034$

Satyanarayana B, Bhanderi P, Debry M, Maniatis D, Foré F, Badgie D, Jammeh K, Vanwing T, Farcy C, Koedam N, Dahdouh-Guebas, F. 2012. A socio-ecological assessment aiming at improved forest 
resource management and sustainable ecotourism development in the mangroves of Tanbi Wetland National Park, The Gambia, West Africa. Ambio 41 (5): 513-526. DOI: 10.1007/s13280-012-0248-7

Sawairnathan MI, Halimoon N. 2017. Assessment of the local communities' knowledge on mangrove ecology. Intl J Hum Capital Urban Manag 2 (2): 125-138. DOI:10.22034/ijhcum.2017.02.02.004

Setiyaningrum IF. 2019. Community perceptions on mangrove forest sustainability in Dukuh Bendo, Jatikontal Village, Purwodadi District, Purworejo Regency, Central Java. IOP Conf Ser: Earth Environ Sci 271 (1): 012017. DOI:10.1088/1755-1315/271/1/012017

Shah MAR, Datta DK. 2010. A quantitative analysis of mangrove forest resource utilization by the dependent livelihoods. In ISEE Conference on Advancing Sustainability in a Time of Crisis. Oldenburg-Bremen, Germany, 22-25 August 2010.

Sinfuego KS, Buot IE. 2014. Mangrove zonation and utilization by the local people in Ajuy and Pedada Bays, Panay Island, Philippines. J Mar Isl Cult 3 (1): 1-8. DOI: 10.1016/j.imic.2013.11.002

Spalding M, Kainuma M, Collins L. 2010. World Atlas of Mangroves. Earthscan, London. DOI: 10.4324/9781849776608

Sreelekshmi S, Veettil BK, Bijoy Nandan S, Harikrishnan M. 2021. Mangrove forests along the coastline of Kerala, southern India: Current status and future prospects. Reg Stud Mar Sci 41. DOI: 10.1016/j.rsma.2020.101573

Sulaiman B, Bambang AN, Purnaweni H, Lutfi M, Mohammed EMA.2019. Coastal community perception of mangroves in Suli subdistrict, Luwu. J Pendidikan IPA Indones 8 (4): 561-569. DOI: 10.15294/jpii.v8i4.21396 [Indonesian]
Sulistyowati E, Astuti P. 2018. Community knowledge related to mangrove conservation law products. SHS Web Conf 54 (03012). DOI: $10.1051 /$ shsconf $/ 20185403012$

Tejada UA, Cauilan AMCC. 2019. Knowledge, attitude, and practice of coastal communities on mangrove benefits, conservation and rehabilitation. Intl J Biosci 14: 461-477. DOI: 10.12692/ijb/14.3.461477

Tomlinson PB. 1986. The Botany of Mangroves. Cambridge University Press, London.

Wahyuni E, Zulhafandi, Hendris, Jarin. 2021. Detection of community knowledge level of economic, ecological benefits and causes of damage to mangrove forest ecosystems. IOP Conf Ser: Earth Environ Sci 748 (1): 012017. DOI:10.1088/1755-1315/748/1/012017

Wang YS, Gu JD. 2021. Ecological responses, adaptation and mechanisms of mangrove wetland ecosystem to global climate change and anthropogenic activities. Intl Biodeterior Biodegrad 162. DOI: 10.1016/j.ibiod.2021.105248

Warren-Rhodes K, Schwarz A-, Boyle LN, Albert J, Agalo SS, Warren R, Bana A, Paul C, Kodosiku R, Bosma W, Yee D, Ronnback P. 2011. Mangrove ecosystem services and the potential for carbon revenue programmes in Solomon Islands. Environ Conserv 38 (4): 485-496. DOI: $10.1017 / \mathrm{S} 0376892911000373$

Warui MW, Manohar S, Obade P. 2020. Current status, utilization, succession and zonation of mangrove ecosystem along Mida Creek, Coast Province, Kenya. Bonorowo Wetl 10 (1): 32-43. DOI: 10.13057/bonorowo/w100103. 